\title{
Pleural calcification, pleural mesotheliomas, and bronchial cancers caused by tremolite dust
}

\author{
S YAZICIOGLU, R ILÇAYTO, K BALCI, B S ȘAYLI, AND B YORULMAZ
}

From the Departments of Chest Diseases and Pathology, Diyarbakir University Medical Faculty, and the Department of Genetics, Diyarbakir and Ankara Medical Faculties, Turkey

ABSTRACT Around the town of Çermik in south-east Turkey there are many deposits of asbestiform心 minerals, some of which are used to make whitewash or stucco. A sample of 7000 of the population $\stackrel{A}{\AA}$ revealed $461(6.5 \%)$ with pleural thickening and calcification, of whom $103(1.47 \%$ of the total $)$ 을 had evidence of interstitial pulmonary fibrosis. Forty-one patients with respiratory cancer were admitted to the Diyarbakir Chest Hospital from around Çermik and from a comparable area of equal population (but without asbestos deposits) in 1977-8. Of these 23 were mesotheliomas, $\frac{\text {, }}{\omega}$ 22 coming from around Çermik. In addition, 11 of the 18 primary bronchial cancers came from ${ }_{\overrightarrow{0}}$ around Çermik. A similar excess of mesothelioma and bronchial cancer had been admitted from $\infty^{\circ}$ the Çermik area in previous years. The whitewash or stucco material has been shown to contain. fibrous tremolite and non-fibrous antigorite/lizardite, chlorite, and talc. A lung biopsy of a patiento from Çermik contained large numbers of tremolite fibres, both free and forming asbestos bodies. There were only occasional chrysotile fibres.

Çermik is a town in south-east Turkey. Since 1973 we have been reporting on investigations into the cause of "Çermik disease." ${ }_{1-6}$ In the present report we add new mineralogical and epidemiological information and discuss the significance of the pleuropulmonary disease in the distriot.
Around the town of Cermik are numerous $\underset{\vec{A}}{\overrightarrow{1}}$ outcrops of asbestiform minerals which are used 3 to make whitewash and stucco for the walls and? roofs of the houses. The first pulmonary $a b-\frac{F}{.}$ normality to be noted was a high prevalence of pleural thickening with calcification. Sub-ô sequently it was noted that, compared with other

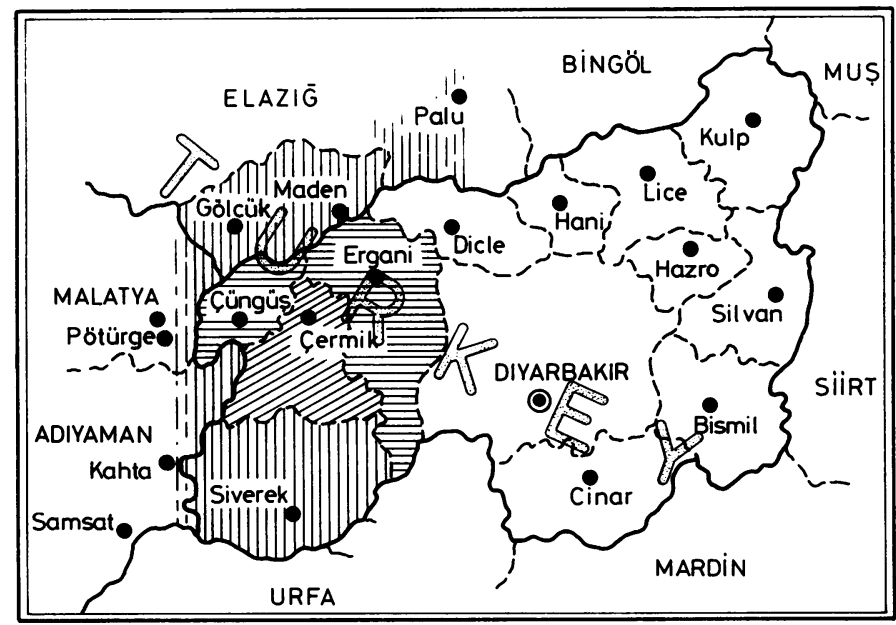

Address for reprint requests: Dr S Y azicioglu, Department of Chest Diseases, Diyarbakir University Medical Faculty, Diyarbakir, Turkey.
Fig 1 Map of south-east Turkey showing the districts served by the Diyarbakir Chest Hospital. The districts $\mathrm{N}$ hatched horizontally and obliquely show: the highest incidence of Çermik disease." Cases have also been reported $\mathbb{N}_{\mathrm{N}}$ from the districts hatched vertically. Asbestos deposits occur and are worked in all these districts, but do not occur in the unhatched districts. 
districts in the area served by the Diyarbakir Chest Hospital, there was a very high incidence of pleural mesothelioma and a relatively high incidence of primary lung cancer. There were also cases of benign fibrosing pleurisy. The clinical picture was similar to that reported from further west in Turkey (Karain). ${ }^{7} 8$

The investigations were undertaken to determine the cause of this local excess of pleural and pulmonary disease in part of Turkey.

\section{Methods}

Figure 1 shows a map of this part of Turkey. The districts where outcrops of asbestiform minerals occur are shaded. Those with vertical shading were not investigated in detail. The outcrops are both most frequent and most frequently exploited in the three districts around Ergani, Çermik, and Çüngüs which are shaded obliquely and horizontally. The population of these three districts is 100800 .

Three thousand, seven hundred men and 3300 women over the age of 20 years were selected from these three districts and investigated with chest radiography. These individuals were those who could be persuaded to attend from villages in which fibrous minerals were known to be used, and do not represent a random sample (table 1). The films were all read by three chest physicians working independently.

Diyarbakir Chest Hospital serves these three districts as well as the others shown on the map. The population of the five asbestos districts listed in table 2, 227000 , is approximately equal to that of the seven non-asbestos districts, 217000 . During the period of the survey (1977 and 1978)

Table 1 Age and sex distributions of pleural calcification and pulmonary fibrosis among 7000 individuals screened by chest radiography

\begin{tabular}{|c|c|c|c|c|c|c|}
\hline \multirow{2}{*}{$\begin{array}{l}\text { Age } \\
\text { groups } \\
(y r)\end{array}$} & \multirow[t]{2}{*}{ Sex } & \multirow[t]{2}{*}{ Numbers } & \multicolumn{2}{|c|}{$\begin{array}{l}\text { Pleural } \\
\text { calcifications }\end{array}$} & \multicolumn{2}{|c|}{$\begin{array}{l}\text { Pulmonary } \\
\text { fibrosis }\end{array}$} \\
\hline & & & Number & $\%$ & Number & $\%$ \\
\hline \multirow[t]{2}{*}{$21-30$} & $\mathbf{M}$ & 774 & 4 & 0.51 & - & - \\
\hline & $\mathbf{F}$ & 740 & 2 & 0.27 & - & - \\
\hline \multirow[t]{2}{*}{$31-40$} & $\mathbf{M}$ & 1169 & 30 & $2 \cdot 56$ & 3 & 0.25 \\
\hline & $\mathbf{F}$ & 1052 & 28 & $2 \cdot 66$ & 1 & 0.09 \\
\hline \multirow[t]{2}{*}{$41-50$} & $\mathbf{M}$ & 1062 & 49 & $4 \cdot 61$ & 7 & 0.65 \\
\hline & $\mathbf{F}$ & 960 & 58 & 6.04 & 6 & 0.62 \\
\hline \multirow[t]{2}{*}{$51-60$} & $\mathbf{M}$ & 632 & 89 & $14 \cdot 08$ & 22 & $3 \cdot 48$ \\
\hline & $\mathbf{F}$ & 441 & 81 & $18 \cdot 36$ & 18 & $4 \cdot 08$ \\
\hline \multirow{2}{*}{$61-70$} & $\mathbf{M}$ & 94 & 70 & $74 \cdot 46$ & 20 & $21 \cdot 27$ \\
\hline & $\mathbf{F}$ & 54 & 32 & $59 \cdot 25$ & 16 & 29.63 \\
\hline \multirow[t]{2}{*}{$70+$} & $\mathbf{M}$ & 13 & 11 & 84.61 & 6 & $46 \cdot 15$ \\
\hline & $F$ & 9 & 7 & $77 \cdot 77$ & 5 & $55 \cdot 55$ \\
\hline \multirow[t]{2}{*}{ Totals } & $\mathbf{M}$ & 3724 & 253 & $6 \cdot 79$ & 57 & $1 \cdot 53$ \\
\hline & $\mathbf{F}$ & 3276 & 208 & $6 \cdot 34$ & 46 & 1.40 \\
\hline Totals & & 7000 & 461 & $6 \cdot 58$ & 103 & 1.47 \\
\hline
\end{tabular}

Table 2 Distribution of 41 patients with malignant mesothelioma and bronchogenic carcinoma between asbestos and non-asbestos districts

\begin{tabular}{|c|c|c|c|c|c|c|c|}
\hline \multirow[t]{2}{*}{ Town } & \multirow{2}{*}{$\begin{array}{l}\text { Popula- } \\
\text { tion* }\end{array}$} & \multirow{2}{*}{\multicolumn{2}{|c|}{$\begin{array}{l}\text { Pleural } \\
\text { neoplasms }\end{array}$}} & \multirow{2}{*}{\multicolumn{2}{|c|}{$\begin{array}{l}\text { Pulmonary } \\
\text { neoplasms }\end{array}$}} & \multicolumn{2}{|l|}{ Total } \\
\hline & & & & & & Number & Rate† \\
\hline \multirow{2}{*}{\multicolumn{8}{|c|}{ Asbestos districts }} \\
\hline & & 5 & $14 \cdot 57$ & 1 & $11 \cdot 66$ & 9 & $26 \cdot 24$ \\
\hline Ergani & 50766 & 9 & $17 \cdot 72$ & 3 & 5.90 & 12 & 23.63 \\
\hline Çüngüş & 15738 & 3 & $19 \cdot 06$ & 1 & $6 \cdot 35$ & 4 & $25 \cdot 42$ \\
\hline Maden & 36594 & 2 & $5 \cdot 46$ & 1 & $2 \cdot 73$ & 3 & $3 \cdot 19$ \\
\hline Siverek & 90027 & 3 & $3 \cdot 33$ & 2 & $2 \cdot 22$ & 5 & $5 \cdot 55$ \\
\hline Totals & 227422 & $22 \ddagger$ & 9.67 & $11 \S$ & $4 \cdot 83$ & 33 & $14 \cdot 50$ \\
\hline \multicolumn{8}{|c|}{ Non-asbestos districts } \\
\hline Lice & 38422 & - & - & 1 & $2 \cdot 60$ & 1 & $2 \cdot 60$ \\
\hline Kulp & 35761 & - & - & 3 & $8 \cdot 38$ & 3 & $8 \cdot 38$ \\
\hline Dicle & 28737 & - & - & 1 & $3 \cdot 47$ & 1 & $3 \cdot 47$ \\
\hline Hani & 18192 & - & - & 1 & $5 \cdot 49$ & 1 & $5 \cdot 49$ \\
\hline Silvan & 52196 & - & - & 1 & 1.91 & 1 & 1.91 \\
\hline Hazro & 16310 & - & - & - & - & - & - \\
\hline Çinar & 28344 & 1 & $3 \cdot 52$ & - & - & 1 & $3 \cdot 52$ \\
\hline Total & 217962 & $1 \ddagger$ & 0.45 & $7 \S$ & $3 \cdot 21$ & 8 & 3.67 \\
\hline
\end{tabular}

* Data from 1970 census

+ Per 100000 inhabitants

$\ddagger \chi^{2}=16.55$ highly significant

$\S \chi^{2}=0 \cdot 38$ not significant

Table 3 Diagnostic procedures carried out on the 41 patients with malignant tumours of lung and pleura

\begin{tabular}{lc}
\hline Diagnostic procedure & Number of cases \\
\hline Bronchoscopy & 28 \\
Bronchial biopsy & 26 \\
Needle biopsy (lung) & 6 \\
Needle biopsy (pleura) & 10 \\
Pleural biopsy at thorascopy & 13 \\
Cytological examination of pleural effusion & 23 \\
Regional node biopsy & 4 \\
Thoracotomy & 2 \\
Cytological examination of sputum & 41 \\
Radiological examination & 41 \\
\hline
\end{tabular}

there were 86 admissions to the Chest Hospital for neoplasms of the lung and pleura. These were analysed and only those 41 patients coming from the five asbestos districts and seven nonasbestos districts were considered. The diagnoses were established by the usual techniques and the frequency with which each diagnostic procedure was used is listed in table 3.

\section{Results}

\section{POPULATION SURVEY}

There were 451 cases of pleural calcification and thickening among the 7000 individuals selected $(6.5 \%$, table 1$)$. There was no significant difference between the sexes but there was an increase in frequency with age. Few cases were seen in the 21-30 year age group but $69 \%$ were affected befcre the age of 70 . The probability of develcping pleural changes appeared to be normally distributed about an average of $50 \%$ at 65 years in this population. 


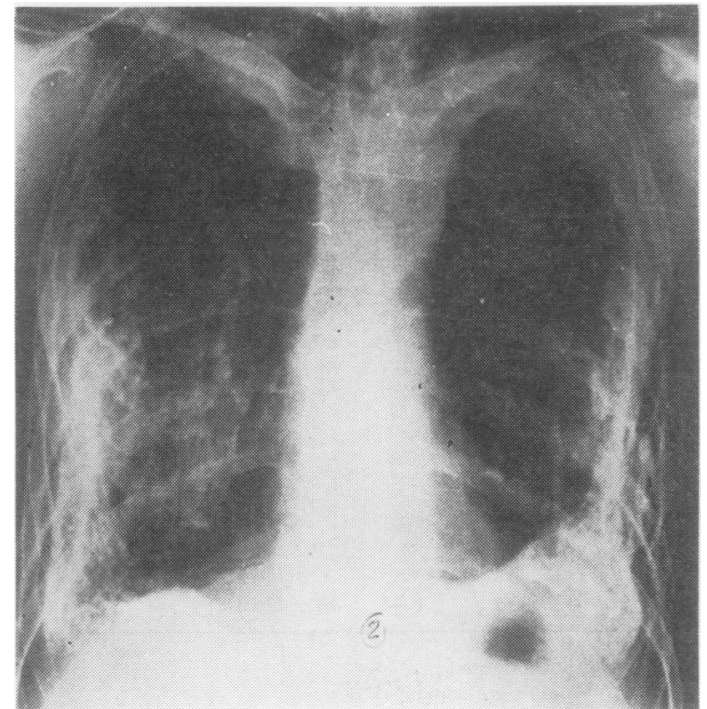

Fig 2 Chest radiograph of a man aged 36 years from Chermik with shell-like calcification of the parietal and diaphragmatic pleurae. There is also thickening of the pleura at both apices.

Pulmonary changes appeared about 10 years later than the pleural changes and affected about $50 \%$ of the population over the age of 70 (table 1). The pleural change was sometimes very extensive. Figure 2 shows advanced pleural calcification in a man of only 36 years also from Çermik.

Only six cases of pulmonary tuberculosis were detected in the population survey, rather fewer than was expected for the general population of this region.

ADMISSIONS TO HOSPITAL

Of the 86 patients with primary tumours of the lungs and pleura admitted to Diyarbakir hospital in 1977-8, 33 came from the asbestos exposed districts and only eight from the control districts (table 2).

There were 23 patients with malignant pleural mesotheliomas, of whom only one came from the non-asbestos districts. The incidence appeared highest in the three districts where the radiological survey had been carried out (Çermik, Ergani, and Cüngüş). In these villages there were 17 cases during the period from a population of 100000 . The rate in Maden and Siverek was less than a third of this. Figure 3 shows a hydropneumothorax with tumour on the chest wall in a man of 65 years from Ergani. The fluid contained hyaluronic acid. Bilateral pleural calci-

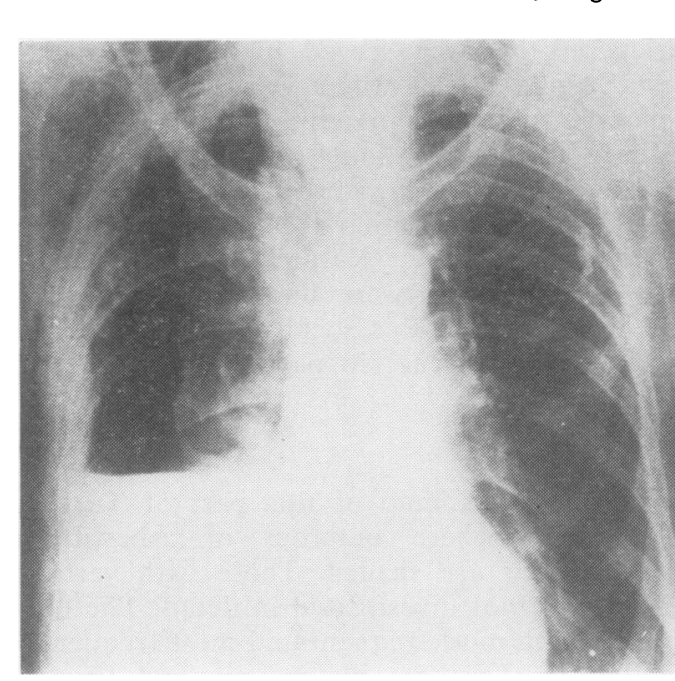

Fig 3 Chest radiograph of a man aged 65 years from Ergani showing a right hydropneumothorax. Tumour (mesothelioma) is seen on the parietal walbo on the right side. The fluid contained hyaluronic acid. Bilateral calcified pleural plaques are present.

fication is also present. Men and women we affected in equal numbers although the thro patients under 40 years of age were all womegh (table 4). All the men and none of the women smoked cigarettes.

Primary bronchial cancer occurred in both asbestos and non-asbestos districts (table 2), cases from the former, and seven from the latte The difference is not statistically significant bet when the figures are combined with those for the

Table 4 Age and sex distribution of 41 patients with pleural and pulmonary malignant tumours

\begin{tabular}{|c|c|c|c|c|c|c|c|}
\hline \multirow{2}{*}{$\begin{array}{l}\text { Age groups } \\
(y r)\end{array}$} & \multicolumn{3}{|c|}{ Pleural tumour } & \multicolumn{3}{|c|}{ Pulmonary tumour } & Total \\
\hline & $\overline{\text { Male }}$ & Female & Total & $\overline{\text { Male }}$ & Fer & Total & \\
\hline $21-30$ & - & - & - & 1 & - & 1 & 1 \\
\hline $31-40$ & - & 3 & 3 & 4 & 1 & 5 & 8 \\
\hline $41-50$ & 1 & 5 & 6 & 1 & 2 & 3 & 9 \\
\hline $51-60$ & 4 & 1 & 5 & 5 & 1 & 6 & 11 \\
\hline $61-70$ & 5 & 2 & 7 & 2 & 1 & 3 & 10 \\
\hline $71+$ & 2 & 一 & 2 & - & - & - & 2 \\
\hline Totals & 12 & 11 & 23 & 13 & 5 & 18 & 41 \\
\hline
\end{tabular}

Table 5 Pleural and pulmonary cancers from abestos and non-asbestos districts in this and previous studies

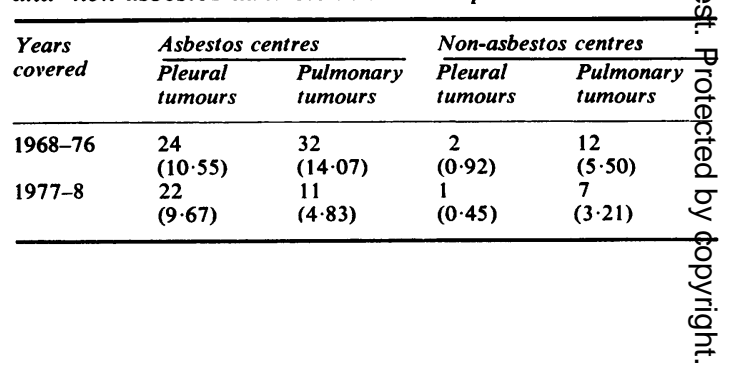




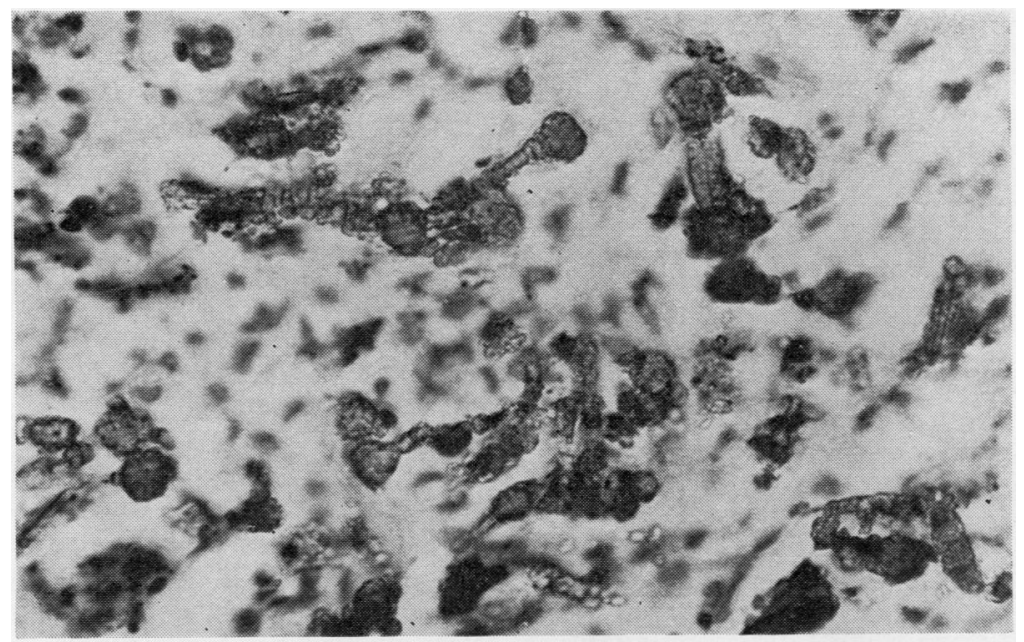

Fig 4 Photomicrograph of lung tissue from a man aged 42 years from Çermik who was shown to have a bronchogenic adenocarcinoma by needle biopsy of a mass in the left lung and biopsy of the regional lymph nodes. The lung contains numerous typical haustrated, bulbous-ended asbestos bodies. Original magnification $H$ and $E \times 600$.

years $1968-76$ the difference is significant $\left(\chi^{2}=\right.$ $7.58 \mathrm{p}<0.001$ (table 5).

The age at which these cancers developed arpeared to be lower than for mesothelioma and they appeared to be more frequent in men (who all smoked) than women (who did not) but these differences were not statistically significant (table 4). Examination of the lung biopsies for dust in the patients from the asbestos area

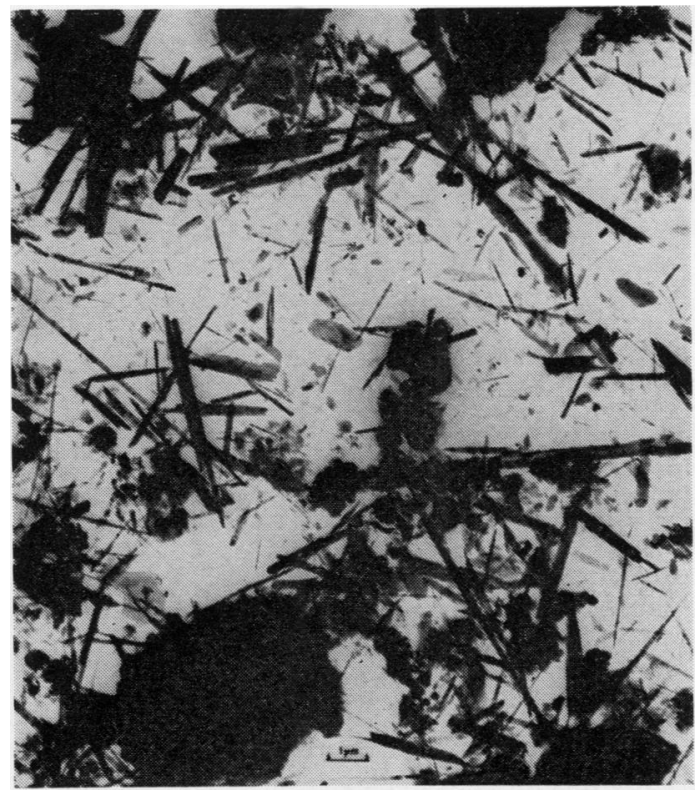

Fig 5 Electron micrograph of stucco whitewash material from Çermik district. Long straight fibres of tremolite asbestos of varying lengths and thicknesses. Original magnification $\times 10000$. showed numerous asbestos bodies (fig 4).

\section{MINERALOGICAL INVESTIGATIONS}

During earlier investigations the whitewash and stucco material had been examined at the State Institute of Mineralogical Research and shown by $x$-ray analysis to contain serpentine minerals and talc. It was assumed that the fibrous element was chrysotile because of the presence of the serpentine. On this occasion new samples of both whitewash or stucco from Cermik an 1 lung material from the patient whose lung is shown in fig 4 were sent for more detailed analysis including electron microscopy and probe analysis of individual fibres.

The stucco was shown to consist of three nonfibrous phases-chlorite, talc, and a serpentine (antigorite/lizardite). The fibrous mineral was an amphibole, tremolite (fig 5). The serpentine mineral did not include chrysotile fibres. In the biopsy specimen most of the fibrous particles were tremolite with a very small percentage of chrysotile (fig 6). The elemental analyses of the fibres of tremolite in the stucco and the biopsy were found to be very similar, suggesting a common source.

\section{Discussion}

The use of stucco material containing a fibrous mineral appears to be the cause of the pleural reactions, pulmonary fibrosis, and malignant tumours of the lungs and pleura in the Cermik area. The inhabitants of Çermik and neighbouring communities are unaware that this material causes these diseases. While initial analysis suggested that the fibrous mineral was chrysotile, 


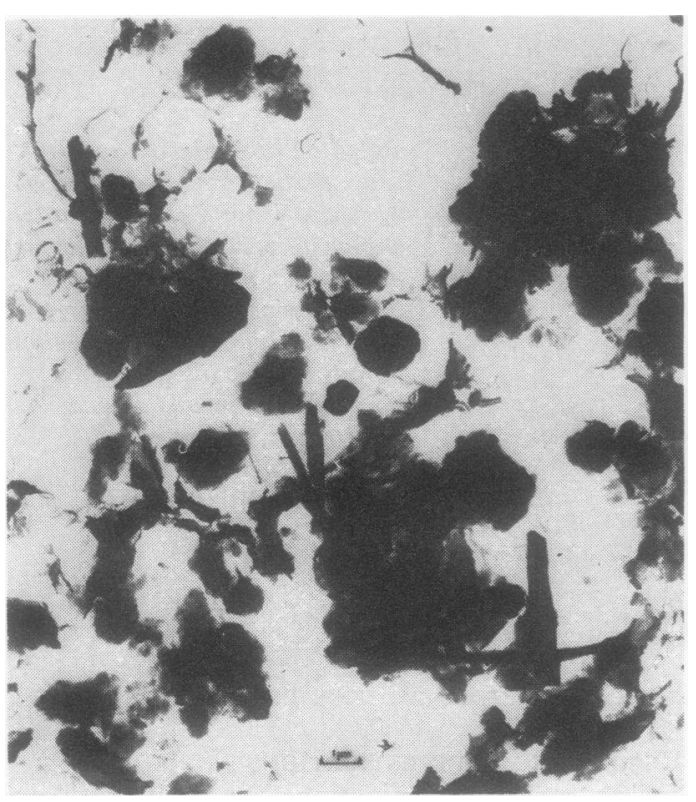

Fig 6 Electron micrograph of dust obtained from the histological section shown in fig 5, showing short straight fibres which on probe analysis had the same elemental composition as the tremolite fibres shown in fig 6. Original magnification $\times 12000$.

more detailed analysis showed it to be the amphibole tremolite. The material also contains talc and non-fibrous serpentine but the detailed composition may vary from place to place within the area.

The material is quarried from the mountains by the male population both for local use and for sale elsewhere. It is used as a whitewash for the walls and floors of the houses. The application is usually done by women who grind the material to a powder and suspend it in water. The process is repeated each year. Consequently householders are repeatedly exposed from an early age, and this exposure can be described as both environmental and occupational but not industrial. The exposure leads to the diseases usually associated with exposure to asbestos. ${ }^{9-11}$ The first obvious sign is the development of "geographic" calcified plaques in the pleura. ${ }^{12-14}$ Radiographic changes of pulmonary fibrosis de-

Table 6 Results of radiological surveys

\begin{tabular}{|c|c|c|c|c|c|}
\hline \multirow[t]{2}{*}{ Survey } & \multirow{2}{*}{$\begin{array}{l}\text { Number of } \\
\text { individuals }\end{array}$} & \multicolumn{2}{|c|}{ Pleural calcification } & \multicolumn{2}{|c|}{ Pulmonary fibrosis } \\
\hline & & Number & $\%$ & Number & $\%$ \\
\hline $\begin{array}{l}\text { Previous studies } \\
\text { This study }\end{array}$ & $\begin{array}{c}15239 \\
7000\end{array}$ & $\begin{array}{l}389 \\
461\end{array}$ & $\begin{array}{l}2 \cdot 55 \\
6 \cdot 50\end{array}$ & $\begin{array}{r}52 \\
103\end{array}$ & $\begin{array}{l}0 \cdot 34 \\
1 \cdot 47\end{array}$ \\
\hline Totals & 22239 & 850 & 3.82 & 155 & 0.69 \\
\hline
\end{tabular}

velop later in a proportion of the population $\overrightarrow{\bar{s}}$ described by Meurman ${ }^{10}$ and Selikoff. ${ }^{11}$

In this environment the exposure is lifelong from birth to death, as long as the individus remains in the area. Probably for this reason the radiographic changes appear early and are vegy extensive. We have encountered many cases of non-malignant pleural effusions associated with these changes similar to the cases described Chretien ${ }^{15}$ and Lemanager. ${ }^{16}$ There is also thick ening of the apical pleura in many cases which has not been described previously.

Although the prevalence of the non-malignant changes increases with age, it is variable in extent. Unless further study indicates wide va ations in levels of exposure this suggests क्षी inherent difference in susceptibility between if dividuals. The incidence of tuberculosis in this community is relatively low but further work needed to see whether exposure to asbest carries any protection against tuberculosis. $\overrightarrow{0}$

Individuals have been detected who spent the infancy in the asbestos area and then moved away. With no further exposure they have developed radiographic changes 20 to 25 years lator and some have subsequently developed a resp $\overline{8}$ atory neoplasm. This emphasises the relative inFcrtance of childhood exposure and of the long latent interval between critical exposure and the first detectable signs of disease. On the other hand adult exposure can also be significant as exemplified by the wife of a government official who lived for only three years, from the age $\overrightarrow{8 f}$ 22 to 25 years, in Cermik and yet was found \$o have pleural calcification when she develop bronchial cancer 35 years later.

A similar clinical picture has been describied in patients outside the areas of the present survoy in Palu and Adiyaman to the North and West (fig 1). The population of the whole area whieh appears to be at risk is over half a million. 80 far the investigation covers about half the area and the numbers of people examined is onlyo small fraction of the total. Although support hos keen provided by the Tuberculosis Units of the Turkish Ministry of Health and Welfare it his cnly been possible to take radiographs of about $5 \%$ of the population at risk.

More important than the benign changes $\mathbb{8}_{7}$ the lungs and pleura are the related neoplasmi. The malignant mesotheliomas are both the most frequent and most clearly related to asbestons exposure. This has been widely reported el where. $^{17-23}$ The bronchial cancers are not onfy slightly less frequent but only a proportion (perhaps one-third) can be attributed to the 
asbestos exposure. Whereas mesotheliomas have been produced experimentally with asbestos fibres, it has been less easy to show that asbestos can cause primary bronchial cancers experimentally. ${ }^{24}{ }^{25}$ In the case of both mesothelioma and bronchial cancer the relatively low frequency of these tumours in comparison with the benign changes suggests that individual susceptibility is also important.

As there is no effective treatment for these diseases it is imperative that efficient preventive measures are taken immediately. They should be aimed at protecting the whole population and not just the men while they quarry the material and the women while they apply the whitewash.

The work was carried out with the continuous help of Hamdi Acan MD, General Director of the Tuberculosis Unit, Ministry of Health and Welfare, Turkey. The special analysis of the stucco material and the dust in the lung biopsy was carried cut by Dr FD Pooley, Department of Mineral Exploitation, University College. Cardiff, Wales.

\section{References}

1 Yazicioglu S. Cermik ve civarinda sik gorulen plevra kalisifikasyonlarinin etyo-patogenesi uzerinde arastirma. Doçentlik Tezi 1973-1974.

2 Yazicioglu S. Asbestosis arastirmasi. DUTFD 1974; 3:61-77.

3 Yazicioglu S. Pleural calcification associated with exposure to chrysotile asbestos in southeast Turkey. Chest 1976; 70:43-47.

4 Yazicioglu S. Öktem K, Ilcayto R, Balci K, Mutlu T. Asbestosis ve solunum sisteminin primer malin tumorleri. Arasindaki iliskiler uzerinde arastirma. Tüb Toraks 1975; 23: 91-103.

5 Yazicioglu $S$, Ilcayto $R$, Balci $K$, Celik $T$, Yorulmaz B. Asbestosisle meydana gelen selim ploreziler. DUTFD 1977; 6:1-12.

6 Yazicioglu S, Öktem K, Ilcayto R, Balci K, Sayli BS. Association between malignant tumors of the lungs and pleurae and asbestosis. A retrospective study. Chest 1978; 73:52-6.

7 Baris YI. Pleural mesotheliomas and asbestos pleuresis due to environmental asbestos exposure in Turkey. An analysis of 120 cases. Hacettepe Bull Med Surg 1975; 8:165-85.

8 Baris YI. Sahin AA, Ozesmi M et al. An outbreak of pleural mesothelioma and chronic fibrosing pleurisy in the village of Karain/Urgup in Anatolia. Thorax 1978; 33:181-92.

9 Kiviluoto R. Pleural calicification as a roentgenologic sign of non-occupational endemic anthophyllite-asbestosis. Acta Radiol 1960; suppl no 194:1-67.

10 Meurman L. Asbestos bodies and pleural plaques in a Finnish series of autopsy cases. Acta Pathol Microbiol Scand 1966; suppl no 181:1-107.

11 Selikoff IJ. The occurrence of pleural calcification among asbestos insulation workers. $A n n N Y$ Acad Sci 1965; 132:351-67.

12 Hourihane DOB, Lessof L, Richardson PC. Hyaline and calicified pleural plaques as an index of exposure to asbestos. A study of radiological and pathological features of 100 cases with a consideration of epidemiology. Br Med J 1966; 1 : 1069-74.

13 Soutar CA, Simon G, Turner-Warwick M. The radiology of asbestos-induced disease of the lungs. Br J Dis Chest 1974; 68:235-52.

14 Teyssier L, Lesobre $\mathbf{R}$. Les plaques pleurales de l'asbestose non professionnelle. J Fr Med Chir Thorac 1968; 22:797-808.

15 Chretien J, Chahinian Ph, Hirsch A, Nebut M. Pleuresies non tumorales de l'asbeste. Rev Fr Mal Resp 1976; 4:87-92.

16 Leménager J, Rousselot P, Mandard JC, I.e Bouffant L, Borel B. Les pleuresies benignes de l'asbeste. Rev Fr Mal Resp 1976; 4:75-86.

17 Wagner JC, Sleggs CA, Marchand P. Diffuse pleural mesothelioma and asbestos exposure in Northwestern Cape Province. Br J Industr Med $1960 ; 17: 260-71$.

18 Lajartre $\mathrm{M}$ de, Cornet E, Corroller $\mathrm{J}$ et al. Etude clinique et professionnelle de 54 mésothéliomes pleuraux diffus. Rev Fr Mal Resp 1976; 4:63-74.

19 Lieben J, Pistawka H. Mesothelioma and asbestos exposure. Arch Environ Health 1967; 14:559-63.

20 Selikoff IJ, Churg J, Hammond EC. Asbestos exposure and neoplasia. JAMA 1964; 188:22-6.

21 Selikoff IJ, Hammond EC, Churg J. Asbestos exposure, smoking and neoplasia. JAMA 1968; 204:106-12.

22 Turiaf J, Chabot J, Basset F. Cancer bronchique et mesotheliome pleural asbestosiques. Poumon Coeur 1966; 24:559-80.

23 Turiaf J, Battesti JP. Le pouvoir cancérigène de l'amiante sur les voies aeriennes. Rev Fr Mal Resp 1976; 4:39-50.

24 Wagner JC, Berry G. Mesotheliomas in rats following inoculation with asbestos. Br J Cancer 1969; 23:567-81.

25 Wagner JC, Berry G, Skidmore JW, Timbrell V. The effects of the inhalation of asbestos in rats. Br J Cancer 1973; 29:252-69. 